A FIEID METHOD USING URAIIINE TO MEASURE

PENEIRATIOIN OF HIGH-ETPICIENCY FILTERS

by

D. E Wisehart

Occupational Hygiene Operation

Occupational Health Operation

Relations and Occupational Health Operation

General Electric Company

Richland, Washington

October 18,1963

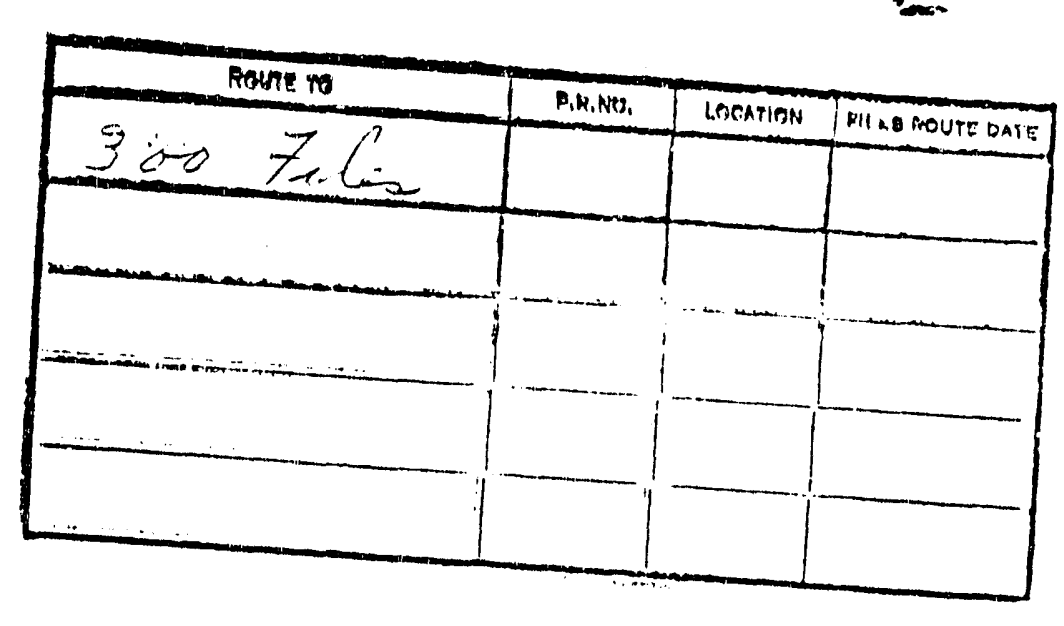

MAR 319

FETUNa TD

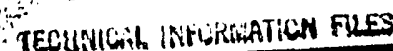


Adley, F. E.

Ager, G. 0.

Anderson, B. V.

Anderson, D. E.

Astley, E. R.

Boya, J. L.

Clark, H. A.

Clark, R. G.

Crose, H. C.

Duncan, J. D.

Eliason, D. E.

Etheridge, E. I.

Finch, I. M.

Forby, L. P.

Fuqua, P. A.

Gi11, W. E.

Goslin, W. 0 .

Heacock, H. W.
Jessen, R. T.

Keigher, D. J.

Norwood, W. D.

Oldiaticer, M. I.

Rice, L. H.

Richardson, W. J.

Rolie, A. G.

Roos, W. H.

Schrendiman, L. C.

Scott, R. H.

Shaver, B. 0 .

Shaw, H. P.

Soldat, J. K.

Thompson, W. V.

Traver, D. I.

Wisehart, D. E.

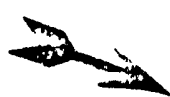

300 Area Files

Record Center

\section{DISCLAIMER}

This report was prepared as an account of work sponsored by an agency of the Unit.d States Government. Neither the United States (jovernment nor aly agency thereof, nor any of their :mployees, makes any warranty, express or implied, or assumes any legal liability or responsi. bility for the accuraci, completeness, or usefulness of any information, appiratus, product, of process disclosed, or represents that its use would not infringe privately owned rights. Refer ence herem io any specific commercial presluct, process, of service by trade name, trademark manuiacturer. or otherwise does not necessirily constitute or imply its endorsenent, recom. mendation, or favoring by the United States Government on any agency thereot. The views and opmiens of authors expressed herein do not necessarlly state or reflect those of the Inted states cowernment or any agency thereof 


\title{
A FIEID METHOD USING URANINE TO MEASURE PENETRATION OF HIGH-EFFICIENCY FILTERS
}

\begin{abstract}
A method has been developed to field test high-efficlency air cleaning filters to measure their efficiency in removing aerosols from contuminated air streams. In certain instances, the efficiency of air cleaning filters may be measured prior to installation. For example, hign-efficiency filters of the "absollice" type are measured for their efficiency of removal of a 0.3 micron dioctylphthalate aerosol from an air stream prior to use at AEC installations. However, defects may occur during or following the installation of the filters in process or building air streams. Therefore, methods of field testing the filters following their installation are desirable.

The efficiency of an installed filter or filters for removal of either a process or artificially produced aerosol can usually be measured. Process aerosols are in most cases difficult to measure quantitatively, however, and usually have varying particle size characteristics. Therefore, an artificial aerosol, uranine, was selected for measurement purposes.

The uranine aerosol may be generated by equipment that is light in weight, low in cost and easily transported. Its particle size distribution and generation rate is reproducible in successive tests and may be varied if desired. Uranine may be determined quantitatively in subinicrogram quantities by flourescent spectroscopy. The determinations require a minimum of time and utilize equipment available to most laboratories.
\end{abstract}

This work was performed under contract No. AT(45-1)-1350 between the U. S. A.tomic Energy Commission and the General Electric Company. 
The uranine aernsol is produced by the generator shown in Figure $I$. Air at 20 pounds per square inch pressure is discharged at a rate of 0.77 cubic feet per minute (STP) through a $\% 60$ drill hole located in the wall of a $1 / 4$ inch copper tube that is sealed at one end. The hole is positioned approximately one-half inch below the surface of a 15 percent uranine in water solution contained in a one liter bottle. As a result, a fine mist is formed. When mixed with dry air the mist droplets dry leaving a solid aerosol. Several drops of octyl alcohol are added to the generator to prevent excessive foaming. A generation rate of 7.4 milligrams per minute of uranine aerosol is obtained. A higher generation rate may be obtained by placing the hole near the surface of the liquid; however, the liquid level must then be kept constant to obtain a constant generation rate.

Samples of the uranine aerosol were collected on electron microscpoe grids by means of a thermal precipitator. The distribution determined by sizing 614 of the particles collected is shown in Figure II. A mass mean diameter of 1.i) micron was obtained from a plot of the aerosol distribution on lngarithmic probability paper. One of the electron photomicrographs obtained is show in Figure III.

The equipment used to perform an efficiency test incluces two air sampling pumps, two air ample filter holders, two airflow metering devices, a uranine generator and a pressure pump. A typical test arrangement is shown in Figure IV. The uranine aerosol is introduced into the air stream upstream of the filter or filters. The uranine in metered samples of the upstream and downstream air is collected on AA Millipore Air Sampling Filters. The uranine content of the sampling filters is determined by an analytical procedure that utilizes the fluorescent properties of uranine. The penetration of the filter or filters by the uranine aerosol is determined by the following equation: 


$$
P=\frac{H_{d}}{M_{u}} \times \frac{Q_{u}}{Q_{d}} \times 100
$$

where $P=$ penetration of a filter or filters by the uranine zerosol, in percent

$W_{d}=$ uranine on ownstream sample filtar, in srams

$H_{L}=$ uranine on upstreem sample filter, in grams

Qu = arflon througin upstrear samile filter, in clibio ieet per minute

$\partial_{d}=$ airflor tirough domstrean sample filter, in clibic feet rer minute

The analysis to aetermine tis uranine colitent of a sample filton is rela. tively simple. The fizter is placed ang side up in a fiass bearer and ter williliters of $8.5 \mathrm{pH}$ buffer of the zuloring composition is added:

$$
\begin{aligned}
& \text { Representative Bufaer Compoticn: }
\end{aligned}
$$

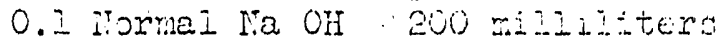

$$
\begin{aligned}
& \text { C.I Holar } \mathrm{H}_{3 O_{4}} \text { - } 1000 \text { mizliz-ters } \\
& \text { Distilled vater - } 600 \text { miliziters } \\
& \text { Total - 2000 milliliters }
\end{aligned}
$$

The sample filter is swirled and soaked in th: buter for aporoimate? ive nimutes to dissolve the uranine. The fiurescence of a portion of the Iiqui: is then measlired in a Beckman Mocel DU Spectrowotcintm with a f'luorescence accessory. Primary and secondary olue Hilowa wie lased in the spectrophotometer. One aizimicrogram ot uranine bas bas aatisoctorily measured by this metiod.

\section{Conclusion:}

A nethod of field testing air cleaning filters has been devlopod. A uranine aerosol is atilized pol tost curposes. Bu usinij several unanino generators and a test tine oi cia nour, a 0.05 percent penetration oi a 150,000 cubic feet ver minte Piter instandation conde be detecter. The method lutilizes a minimun of equizment and twie. 
(4)

UNCLASSIFIED

HW -79303

References:

RobInson, Elmer: Atmospheric Tracer Techniques Using Aerosols Instrument Society of America Conference Reprint \# 11-SF60. 


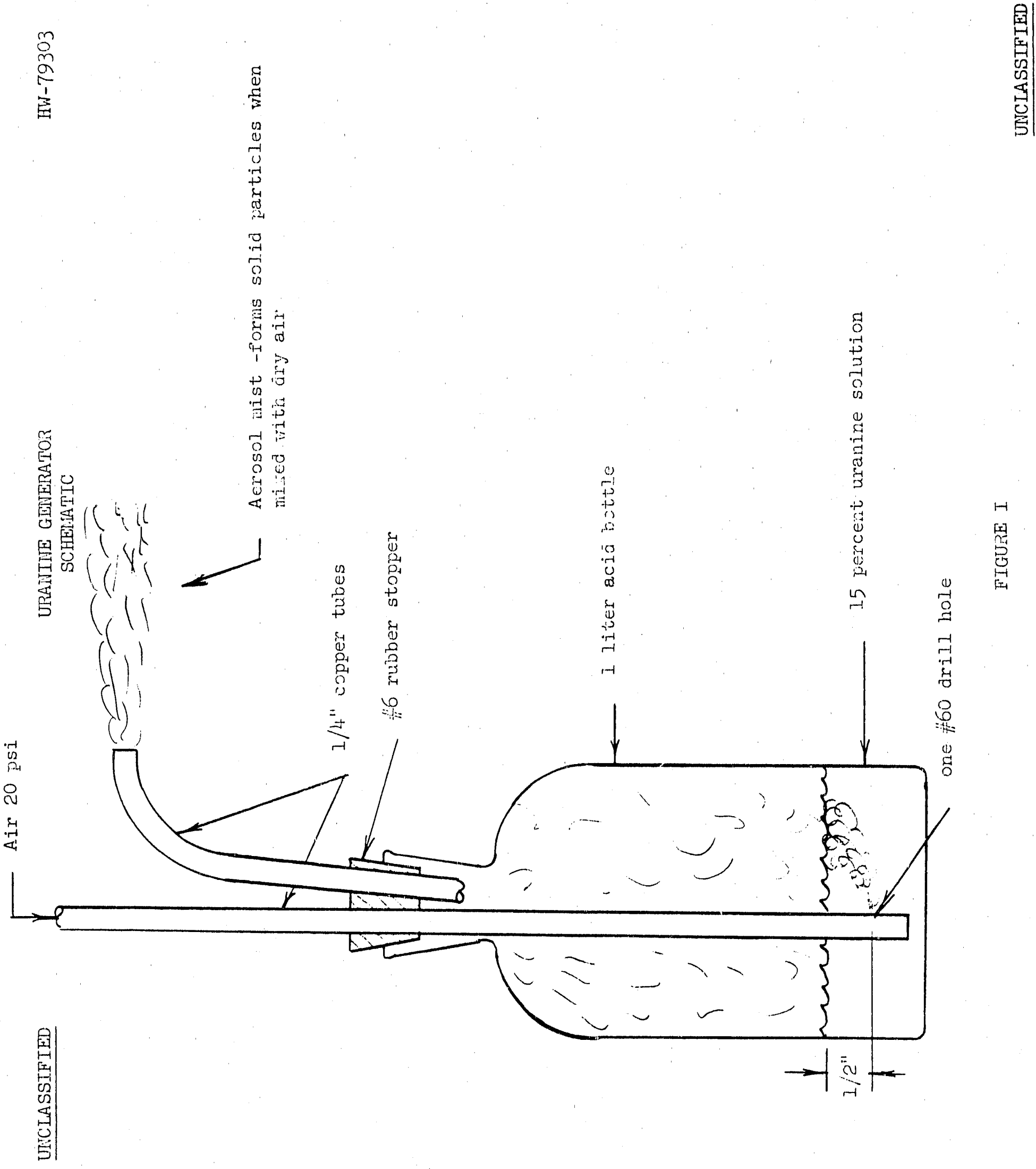



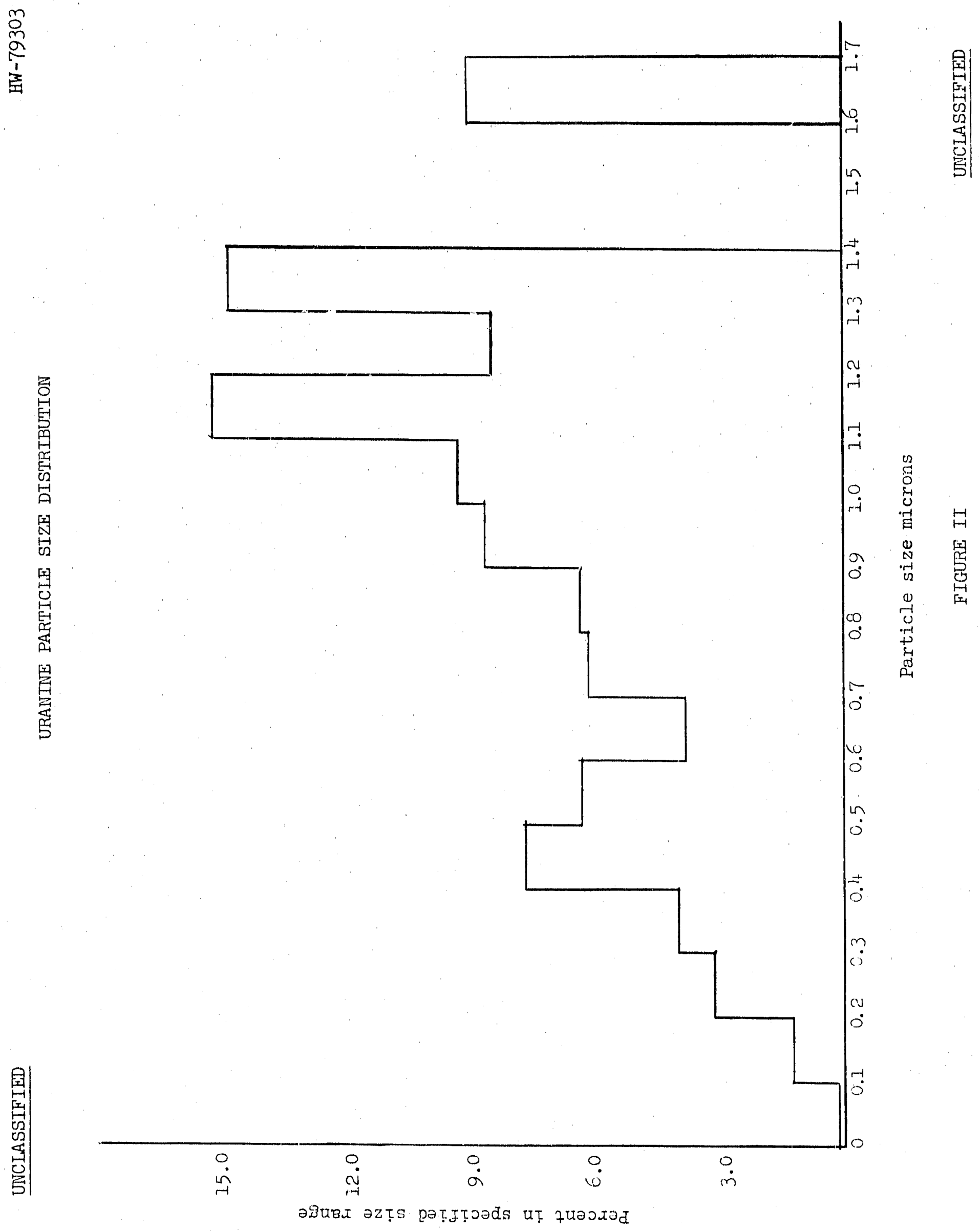
$H W-79303$

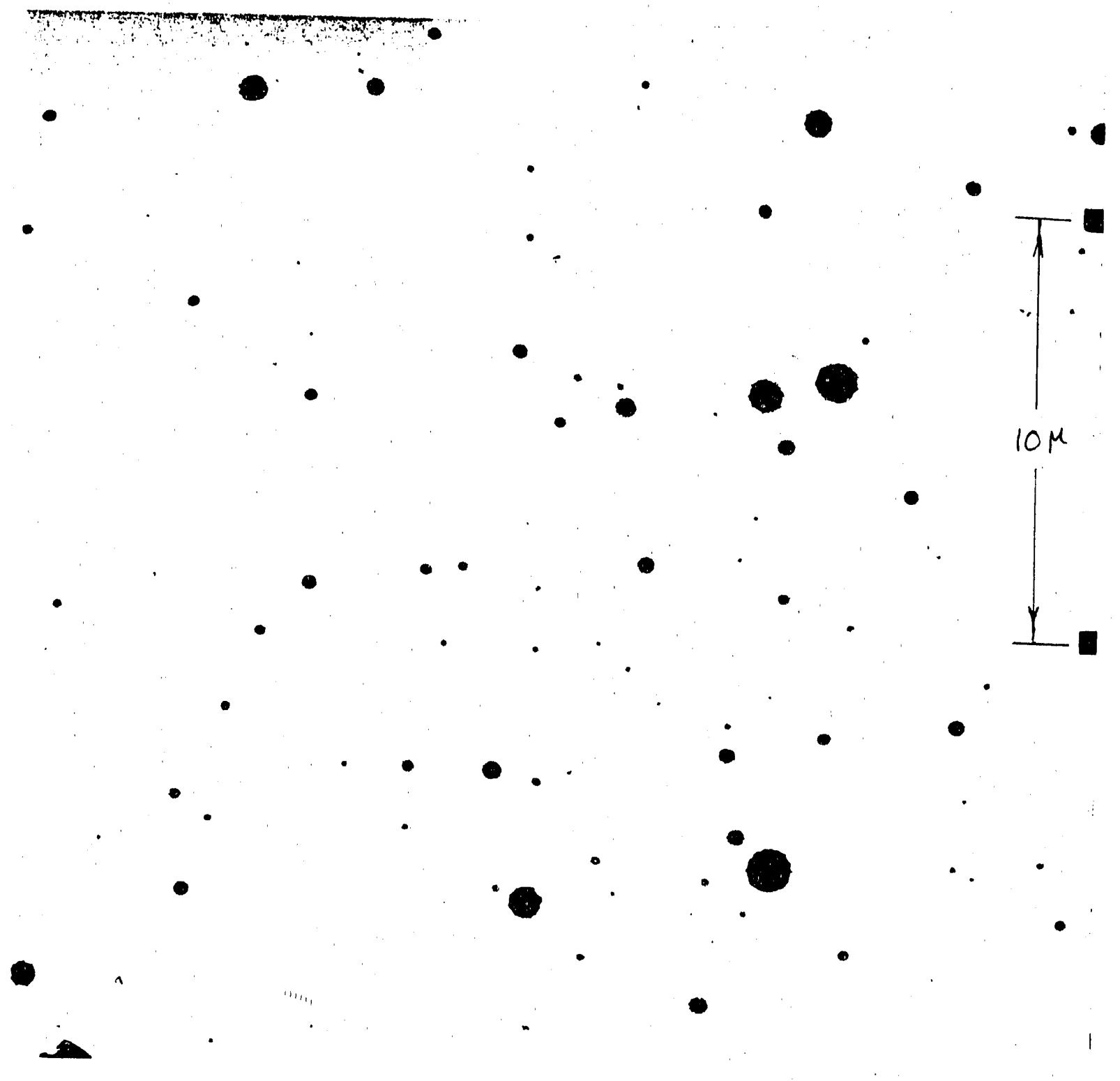

FIGURE III

URANINE AEROSOL 
$m$
0
$n$
$a$
1
$\vdots$
$n$

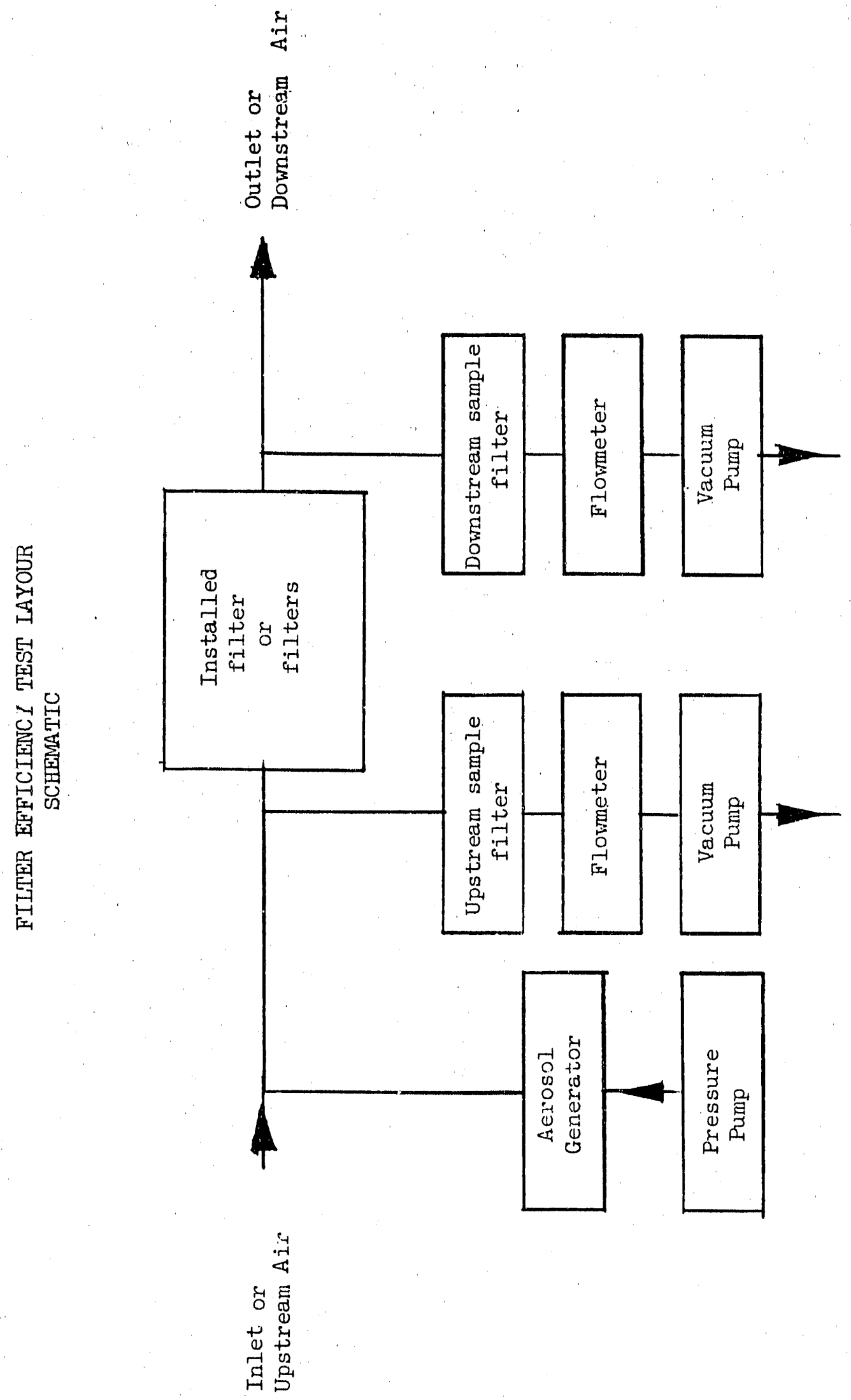

辟
$\vdots$
$\vdots$
$\vdots$
$\vdots$
$\vdots$
$\vdots$ 


$$
\text { mon }
$$

